UDC 94(517.3)

\title{
COLLECTIVE LEADERSHIP AND THE STRUGGLE FOR POWER IN THE MONGOLIAN PEOPLE'S REPUBLIC IN THE 1950S: YU. TSEDENBAL AND D. DAMBA
}

\section{Otroshchenko}

DSc (History), Senior Fellow

A. Yu. Krymskyi Institute of Oriental Studies, NAS of Ukraine

4, Hrushevskoho Str., Kyiv, 01001, Ukraine

khalkhamongol@i.ua

ORCID ID: 0000-0003-3508-7954

The article, based in particular on unpublished sources, analyzes the rivalry between the Yu. Tsedenbal and D. Damba, Prime Minister and First Secretary of the Mongolian People's Revolutionary Party in the political realities of the Mongolian People's Republic in the 1950s (collective leadership period). According to the author, in addition to the struggle for power that took place during the previous decades between the Mongolian prime minister and the leader of the Mongolian People's Revolutionary Party, in this case, there were fundamental differences in the views of the Mongol rulers. These were different views on the pace and conditions of cooperation of Arat farms, on the demarcation of the border between the Mongolian People's Republic and the USSR - extremely important things for Mongolian society.

The most acute direction in the mutual struggle of the two Mongolian political leaders was the rethinking and investigation of the political repressions that took place in the 1930s and 1940s in the Mongolian People's Republic. On the one hand, this tragedy of the Mongol people remained relevant for decades, appealed to by various cohorts and generations of Mongolian politicians in the second half of the $20^{\text {th }}$ century. On the other hand, then the investigation of the crimes of the previous regime served as a powerful weapon in the struggle for sole power in the socialist country, following the example of Soviet party leader N. Khrushchev. Thus, the second half of the 1950s was a difficult ordeal for Yu. Tsedenbal, who fought not only for power that began to slip out of his hands but also for his own past. Mongolian political life was influenced by the unstable political situation in the Soviet ruling elite and the Eastern Bloc and the imposition on each other of the powers of the head of state and the head of the party in the countries of the socialist camp. The decisive factor was also the degree of Soviet support for a particular policy, which was based primarily on the latter's loyalty to the USSR. The removal of D. Damba and his supporters from the political arena did not deprive Yu. Tsedenbal of serious opposition and further challenges to his power, which proves that inside the Mongol elite the reasons for dissatisfaction with the political line of the Prime Minister were quite objective.

Keywords: Mongol People's Republic, USSR, Mongolian People's Revolutionary Party, prime-minister, First Secretary of the Mongolian People's Revolutionary Party, collective leadership, Yu. Tsedenbal, D. Damba, political repressions

(C) 2021 I. Otroshchenko; Published by the A. Yu. Krymskyi Institute of Oriental Studies, NAS of Ukraine on behalf of The World of the Orient. This is an Open Access article distributed under the terms of the Creative Commons Attribution License (https://creativecommons.org/licenses/by$\mathrm{nc} / 4.0 /)$. 
КОЛЕКТИВНЕ КЕРІВНИЦТВО ТА БОРОТЬБА ЗА ВЛАДУ В МНР 1950-Х РР.: Ю. ЦЕДЕНБАЛ I Д. ДАМБА

\section{I. В. Отрощенко}

Ю. Цеденбал (монг. Ю. Цэдэнбал; 1924-1990) обійняв посаду прем’єр-міністра Монгольської Народної Республіки (МНР) у 1952 р., через кілька місяців після смерті прем'єр-міністра МНР маршала Х. Чойбалсана, протеже якого він був. Водночас Ю. Цеденбал зберіг посаду генерального секретаря ЦК МНРП (Монгольської народно-революційної партії), яку обіймав $з$ 1940-х рр. За традицією, що склалася за попередників Цеденбала, посада прем'єр-міністра давала фактично повноту влади в країні, навіть коли прем'єр не був генеральним або 1-м секретарем МНРП. У квітні 1954 року Ю. Цеденбал з огляду на негативне ставлення до практики концентрації влади в одних руках, що склалося в Москві в перші постсталінські роки, залишає посаду генсека [История Монголии... 2007, 217]. Одночасно було скасовано посаду генерального секретаря ЦК МНРП і натомість запроваджено посаду першого секретаря, яку обійняв Д. Дамба (1908-1993). Останній з 1947 р. був другим секретарем ЦК МНРП. Такий стан справ протривав 5 років, допоки Дамба навесні 1959 р. не був усунений від влади. Тлумачачи події на політичній сцені МНР згідно з радянськими суспільно-політичними реаліями, західні спостерігачі підкреслювали, що в період, коли Дамба очолив партію, а Цеденбал - уряд, Монголія приступила до власного експерименту з колективним керівництвом (рос. "коллективное руководство") [Current Intelligence Weekly Summary - далі CIWS, September 29, 1960]. За влучним визначенням Короткого оксфордського словника політики та міжнародних відносин, принцип колективного керівництва зазвичай застосовувався в радянській партійній ієрархічній системі відразу ж після смерті або відсторонення від посади генерального секретаря. Це відбувалося після смерті Леніна в 1924-му, смерті Сталіна в 1953-му і після зняття з посади Хрущова в 1964 р. Однак керівна роль нового генерального секретаря дуже скоро відновлювалася [The Concise Oxford Dictionary... 2018]. На прикладі колективного керівництва в МНР бачимо, що перед нами випадок, по-перше, коли колективне керівництво було запроваджене лише через два роки після смерті “вождя”, по-друге, згодом партійний очільник фактично зазнав поразки від голови виконавчої гілки влади, який повернув собі першість у партійній ієрархії.

Суспільно-політичної ситуації в МНР 1950-х рр., зокрема боротьби за владу між тамтешніми можновладцями, торкалися західні монголісти: Р. Рупен, К. Етвуд, С. Радченко, А. Сандерс та ін. [Rupen 1960; Atwood 2004; Radchenko 2005; 2006; Sanders 2010], а також Ш. Г. Надіров ${ }^{1}$ у книжці “Цеденбал. 1984 год” [Надиров 1995]. Кілька років тому вийшла книжка монгольського урядовця Й. Отгонбаяра “Дашийн Дамба” (Улаанбаатар, 2017), присвячена одному з героїв цієї статті². Але цей період монгольської історії, зважаючи на брак розсекречених та доступних дослідникам архівних документів, ще чекає на грунтовне висвітлення. Дослідженню сприяє ознайомлення з аналітичними матеріалами (зараз би сказали - аналітичними розвідками) ЦРУ другої половини 1950-х - початку 1960-х рр. (де висвітлювалися, зокрема, розвиток та стан справ у МНР), насамперед "Current Intelligence Weekly Summary” (CIWS), а також документами з фонду “В. М. Молотов” Російського державного архіву соціально-політичної історії (РГАСПИ) [РГАСПИ, ф. 82, оп. 2, д. 1280-1281]. Велике значення для дослідження мають оприлюднені інтерв'ю 3 очевидцями та учасниками процесів, що відбувалися на монгольському Олімпі в середині минулого століття: "Socialist Devotees and Dissenters: Three TwentiethCentury Mongolian Leaders” (Осака, 2011) і “Цеденбал и его время” (М., 2006)․ Погляд радянської сторони на монгольських лідерів можна уявити завдяки, зокрема, збірці інтерв”ю “Сто сорок бесед с Молотовым” (Москва, 1991). 
Як справедливо зазначають деякі дослідники, Ю. Цеденбал почав свою політичну кар'єру довжиною в життя як генеральний секретар партії в ніжному віці 23 років, оскільки його відданість Радянському Союзу була очевидною і непохитною [Myadar 2017, 17]. 3 другого боку, колишній колега Цеденбала Б. Нямбуу, член ЦК МНРП, визнавав, що в той час у Монголії не вистачало професійних кадрів, особливо після політичних репресій кінця 1930-х рр. Молодих професіоналів у галузі фінансів та економіки, які володіли російською мовою, як-от Цеденбал, було досить мало [Socialist Devotees and Dissenters... 2011, 201]. Такі, як Цеденбал, представники новоствореної еліти Монголії були найбільш "реформованим Іншим", відомим під назвою “люди-імітатори” (mimic men) в колоніальному дискурсі, і стали посередниками між колоністами та колоніальними підданими [Myadar 2017, 17]. Таке трактування його постаті також є справедливим. Як відомо, Цеденбал був одружений з радянською громадянкою, вдома розмовляли російською, Радянський Союз сприймався насамперед як зразок для наслідування.

Непрості відносини між Цеденбалом і Дамбою, мабуть, почали складатися одразу після смерті Х. Чойбалсана, коли вони опинилися серед головних претендентів на посаду прем'єра ${ }^{4}$. Тоді пауза з вибором першої особи МНР розтягнулася на довгих 4 місяці. Л. І. Шинкарьов пише: "Мабуть, єдиним, хто міг конкурувати з Цеденбалом, був Д. Дамба. Сам з аратів, він вважався людиною, яка розуміє свій народ, яка вміє переконувати - своєю образною, нехай не зовсім літературною, мовою" [Шинкарев 2006, 91]. Б. Нямбуу, який тривалий час працював під проводом Дамби як секретаря одного з місцевих партійних осередків, характеризував його так: “Пан Дамба був дуже мудрим, добре знав життя громадян і мав добру пам'ять. Багато років працював в армії. Однак він не закінчив російської школи. Справді, він ніколи не відвідував навіть монгольської школи. Всього він навчився завдяки самоосвіті власними силами" [Socialist Devotees and Dissenters... 2011, 188]. Схоже, що й сам Дамба не залишався осторонь від політичної боротьби, розповідаючи про наявні в монгольському політикумі настрої - бажання призначити на посаду прем'єра саме халхасця 5 , а не дербета ${ }^{6}$ (дербетом був Ю. Цеденбал) - і приписуючи таку агітацію іншому своєму супернику - Ч. Суренжаву [РГАСПИ, ф. 82, оп. 2, д. 1281, л. 76].

В. М. Молотов, колишній міністр закордонних справ СРСР (1939-1949, 19531956), згадуючи монгольських правителів, відверто зазначав, що після смерті Х. Чойбалсана "треба було когось призначати. Пропонували Дамбу. Подивився я на цього Дамбу і вирішив призначити Цеденбала. Він до нас добре ставиться” (13.04.1972, 09.05.1972) [Сто сорок бесед... 1991, 114]. Через кілька років, повернувшись до цієї теми, Молотов скаже більш докладно: «Дамбу я добре знав. Це відстала людина. Перший секретар певний час. Цеденбала усунули. Я якраз приїхав, коли Цеденбал Головою Ради Міністрів був, а Першим секретарем Дамбу зробили․ А він хитрий такий монгол, обережний, російською не розмовляє. Одне це вже свідчить про те, що він для керівництва не годиться, - треба читати "Правду”, “Комуніст”. А Цеденбал вивчився в Іркутському фінансовому інституті і там одружився 3 росіянкою. Вдома в нього бібліотека» (07.12.1976) [Сто сорок бесед... 1991, 115].

Натомість деякі західні дослідники вважають, що саме завдяки підтримці Дамби Цеденбал виграв прем'єрське крісло і незабаром після цього Суренжав був відсторонений від влади та висланий до Москви. Він був повернутий у 1957-му і допоміг Цеденбалу понизити на посаді Дамбу в листопаді 1958-го, а потім і остаточно вигнати останнього в березні 1959 р. [Radchenko 2006, 102; Atwood 2004, 548]. Водночас сам Суренжав тоді ж, у березні 1959 р., був відсторонений від влади разом із Дамбою.

Перехід Д. Дамби на першу позицію в керівництві ЦК МНРП, як видно, загострив суперництво двох провідних монгольських політиків. Ш. Надіров пише: “У Москві, як відомо, М. С. Хрущов під приводом підвищення керівної ролі КПРС 
прибрав до рук всі важелі влади, ставши першою особою в державі. Наслідуючи приклад радянського лідера, Д. Дамба, який підігрівався своїм найближчим оточенням, також став домагатися першості, прагнучи відтіснити Ю. Цеденбала на другу роль у країні” [Надиров 1995, 74]. Зокрема, Д. Дамбі симпатизував радянський посол в МНР В. І. Писарев (1953-1957) [Шинкарев 2006, 92]. Цеденбал, маючи радянську вищу освіту, зневажав Дамбу як “відсталу" людину, яка ухилялася від роботи, щоб відвідати худон ${ }^{8}$, не була книжником і не писала власних промов [Atwood 2004, 126]. Тоді як Б. Нямбуу, навпаки, вважав (напевно суб'єктивно), що порівняно $з$ Цеденбалом “пан Дамба був дуже проникливою, яскравою та чудовою людиною. Секретар Ю. Цеденбал міг зникнути на задньому плані Дамби та Чойбалсана. Можливо, тому він став відомим лише після Чойбалсана" [Socialist Devotees and Dissenters... 2011, 199].

Найгострішим напрямом у взаємній боротьбі двох монгольських політичних лідерів волею обставин стало переосмислення політичних репресій 1930-1940-х рр. у МНР. Відразу ж на засіданні ЦК МНРП під головуванням Дамби була прийнята постанова про створення комісії з розслідування "Порт-Артурської справи" (19501952) $)^{9}$ У травні 1955 р. Політбюро ЦК МНРП розглянуло висновки комісії, яка розслідувала цю справу, та ухвалило рішення звільнити помилково засуджених i притягнути до відповідальності відповідних посадових осіб за грубі порушення закону ${ }^{10}$.

Й. Отгонбаяр зазначає, що саме під час ХХ з'їзду ЦК КПРС (14-25.02.1956) відносини між двома монгольськими лідерами, які й так були непростими, були серйозно зіпсувалися і що монгольські ЗМІ навіть не згадували ані про процес зустрічі, ані про главу делегації ${ }^{11}$. Тоді радянська сторона запропонувала, щоб іноземні делегації очолювали партійні очільники. Монголи вийшли з делікатної ситуації в такий спосіб: Ю. Цеденбал виступив від імені МНРП у Верховній Раді СРСР, а Д. Дамба був прийнятий окремо М. С. Хрущовим як глава делегації. Про події, що сталися під час того візиту до Москви, дружина Цеденбала А. І. Філатова згадувала: «Того вечора до нас в особняк приїхав Д. Дамба, тоді генеральний секретар ЦК МНРП. Вони з Цеденбалом проговорили всю ніч. Вранці чоловік був сам на себе не схожий, мені стало його дуже шкода... Виявляється, Дамба звинувачував Цеденбала в причетності до репресій, які були в Монголії в 30-40-ві роки ${ }^{12}$. У Радянському Союзі реабілітація жертв сталінського терору почалася ще в 1953 році, а до початку роботи XX з'їзду партії всюди створювалися комісії з перегляду великих репресивних акцій колишнього режиму. Перед керівництвом КПРС Дамбі дуже хотілося видаватися вірним провідником радянської політики. Йому потрібні були “гучні справи”. Цеденбал був схвильований. “Зрозумій, все, що ми з тобою вчора говорили у зв”язку з анонімкою, - дурниця в порівнянні з тим, що затіває Дамба..." - сказав Цеденбал» [Шинкарев 2006, 173].

У квітні 1956 р. культ особи Х. Чойбалсана був підданий критиці на 4-му пленумі ЦК МНРП, разом із підтримкою рішень ХХ з’їзду КПРС. За спогадами Б. Нямбуу, Дамба вважав, що “ті, хто зробив культ особи поширеним у Монголії і вичистив безліч людей як політичних злочинців, мають бути викриті і притягнуті до політичної відповідальності!” [Socialist Devotees and Dissenters... 2011, 188]. Ю. Цеденбал спробував звести до мінімуму негативні наслідки культу особи, зазначивши, що “в Монголії була проведена політична чистка, але в набагато менших масштабах, ніж у Радянському Союзі" [Socialist Devotees and Dissenters... 2011, 188]. У ті дні чимало членів Політбюро ЦК МНРП підтримували позицію Д. Дамби. Багато хто вважав, що, оскільки “секретар Ю. Цеденбал працював з Х. Чойбалсаном протягом багатьох років, він також має взяти на себе відповідальність за культ особи, який домінував у Монголії! Він не має ухилятися від відповідальності за страту багатьох людей як політичних злочинців!” [Socialist Devotees and Dissenters... 2011, 188]. 
Б. Нямбуу підкреслював, що для Цеденбала захист Чойбалсана фактично означав захист самого себе, оскільки за часів Чойбалсана кількість осіб, заарештованих Міністерством внутрішньої безпеки за особистої участі Ю. Цеденбала, сягала 1400, багато $з$ них були страчені ${ }^{13}$ [Socialist Devotees and Dissenters... 2011, 194]. Отже, за словами С. Радченка, Цеденбал не був палким прихильником “відлиги”, яка не лише відкрила для вивчення його власний статус соратника Чойбалсана, а й послабила його владу [Radchenko 2005, 276].

В МНР була сформована спеціальна комісія для перегляду справ репресованих у 1930-1940-ві pр. на чолі з Б. Ширендевом, майбутнім президентом Академії наук МНР. 36 членів комісії пів року вивчали документи, зустрічалися з родичами загиблих, зі свідками та тими, хто ці репресії здійснював [Шинкарев 2006, 174]. Дамба підтримав надання комісії доступу до надсекретних файлів Міністерства внутрішніх справ, тоді як Цеденбал виступив проти і рішуче підтримав припинення роботи комісії. "У 1957 році доля Цеденбала багато в чому залежала від мене як голови комісії з реабілітації жертв репресій; за виявленими нами матеріалами його могли повалити. Проте я цього не хотів, все-таки він освічена людина", - згадував через десятиліття по тому один з найвідоміших монгольських істориків [Шинкарев 2006, 175]. Судячи з усього, Цеденбал цілком усвідомлював хиткість свого становища, зокрема в 1957 р. він навіть хотів заарештувати Б. Ширендева та іншого свого політичного суперника як “імперіалістичних шпигунів”, проте Дамба переконав його відкласти, а потім зняти звинувачення [Atwood 2004, 126]. Попереджений Дамбою про такі наміри прем'єра Ширендев швидко відмовився від державної роботи та вирушив здобувати науковий ступінь до Москви (1957-1960рр.) [Atwood 2004, 501].

Наскільки жахливим у психологічному плані виявився для Цеденбала той період розслідувань, стає зрозуміло з вищезгаданої праці “Цеденбал и его время" 14 [див.: Шинкарев 2006, 173-176]. Його підозрювали, зокрема, у причетності до “Порт-Артурської справи”. Як видно, Д. Дамба надихався прикладом М. Хрущова (коли виявлені в архівах матеріали щодо причетності інших членів вищого партійно-державного керівництва СРСР до репресій були використані для їхньої дискредитації [Даниленко 2008, 8]). Дамба бачив, що 1-му секретареві ЦК КПРС вдалося змістити главу уряду СРСР Г. Маленкова, до речі, також співучасника політичних репресій.

Ще одним напрямом, у якому погляди обох політиків, схоже, розійшлися, стало питання демаркації кордону. Кордон між СРСР і Монголією на тувинсько-монгольській ділянці залишався невизначеним, і у зв'язку зі зростанням населення в Туві та Монголії, розвитком народного господарства там дедалі частіше виникали непорозуміння. Переговори щодо кордону відбулися в 1957-1958 рр. Радянсько-монгольський кордон у межах тувинсько-монгольської ділянки був чітко визначений і демаркований угодою від 26 березня 1958 р. Відомий радянський сходознавець і дипломат М. С. Капіца зауважував, що при укладанні договору в 1958 році недостатньо були враховані потреби прикордонного населення Убсунурського аймака МНР у пасовищах [Капица 1996, 200]. Він визнавав, що стара лінія кордону на окремих ділянках відхиляється в бік монгольської території і варто було б домовитися про усунення таких відхилень на кордоні шляхом рівноцінного обміну ділянками, якщо монгольська сторона вважатиме прийнятною таку форму рішення. Згодом делегації двох країн провели перевірку та уточнення кордону XVIII-XIX ст., і 19 жовтня 1976 року був підписаний новий договір про проходження радянсько-монгольського кордону (див.: [Капица 1996, 201]).

Наскільки важкими і резонансними були для монгольської сторони ці переговори, свідчить інформація американських спецслужб про те, що на початку 1958 року, коли Радянський Союз нібито захопив територію біля озера Хубсугулу (монг. Хөвсгөл нуур), багату родовищами кобальту, спалахнуло повстання, яке було швидко придушене [CIWS, April 16, 1959]. Під час переговорів щодо кордону 1930-1940-х рр. 
монгольський уряд завжди наполягав на уточненні лінії кордону згідно з історичними даними, переконуючи, що повернення громадянам прикордонних районів їхніх споконвічних пасовищних земель може запобігти конфліктам між аратами прикордонних районів з обох боків (більше див.: [Отрощенко 2019, 86-93]). Схоже, що такої ж лінії дотримувався й перший секретар ЦК Д. Дамба під час переговорів 1957-1958 pр., тоді як прем’єр Ю. Цеденбал зайняв абсолютно іншу позицію. У будь-якому разі на III пленумі ЦК МНРП (березень 1959 р.) Цеденбала звинувачували в тиску на Дамбу з цього питання ${ }^{15}$. За результат цих переговорів відповідальність на Цеденбала покладав і Ц.-О. Лоохууз (Ц. Лохуз) - державний та політичний діяч МНР, який у 1964 р. разом з деякими іншими монгольськими політиками виступив проти Ю. Цеденбала: “Ю. Цеденбал був людиною, яка час від часу робила дивні речі. Людям ця справа зовсім не сподобалася. Чому ніхто не міг говорити від імені Батьківщини?" [Socialist Devotees and Dissenters... 2011, 115]. За словами Лоохууза, багато монголів дивувалися, як Цеденбал міг віддати частину своєї рідної землі ${ }^{16}$ лише для того, щоб здобути прихильність іноземців. Інші джерела також свідчать, що відповідальність за неоднозначну угоду покладалася саме на прем'єра. Зокрема, Current Intelligence Weekly Summary від 16 квітня 1959 р. зазначає, що в самій Монголії “висловлюється презирство до готовності прем’єр-міністра Цеденбала прийняти вимоги СРСР, здебільшого тому, що його дружина росіянка" [CIWS, April 16, 1959]. Сходознавець, історик-міжнародник С. Радченко також зазначає, що Цеденбал погодився передати Радянському Союзу велику ділянку землі на північному заході Монголії, всупереч запереченню свого міністра закордонних справ ${ }^{17}$ [New Documents on Mongolia... 2007/2008, 343].

Видатний американський монголіст Р. Рупен зазначав, що, наприкінці 1957 - на початку 1958 р., здавалося, у боротьбі за владу перемагав саме Дамба [Rupen 1960, 142]. Дослідник підкреслював, що в листопаді 1957 р. делегацію МНР до Радянського Союзу, до складу якої входили як Дамба, так і Цеденбал, очолював Дамба і лише Дамба стояв серед тих, хто приймав парад на Красній площі в Москві, коли СРСР святкував 40-ву річницю Жовтневої революції. У травні 1958 р. Дамба, а не Цеденбал, представляв МНР на важливій конференції з економічного співробітництва в

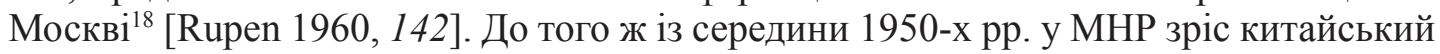
вплив, і вважалося, що Дамба користується підтримкою КНР ${ }^{19}$ [Geisler 1959, 183].

Дамба, здавалося, контролював ХІІІ з'їд МНРП в березні 1958 року (див.: [МАХН-ын 13 их хурлын материал... 1958]). Зокрема, він “напав" на Чойбалсана, зауваживши, що культ особи, який його оточує, призвів до грубих порушень “революційної законності” та зниження ролі партії. I хоча Дамба виступав за колективне керівництво, на думку західних експертів, такий наступ свідчив про його власні повноваження та статус [CIWS, April 3, 1958].

Ще болючішими стали зауваження Дамби щодо державної політики примусу аратів переходити до кооперативного господарювання. Підкреслюючи, що рух до кооперативних господарств має бути добровільним і якось “винагороджуватись”, Дамба чітко розумів, що темпи модернізації мають враховувати традиційні культурні моделі Монголії ${ }^{20}$. Хоча раніше сам закликав аратів вступати в сільськогосподарські спілки, стверджуючи при цьому, що кооперативне тваринництво буде створено “на суто добровільній основі”, а ХІІІ з”їзд МНРП (березень 1958 р.), проаналізувавши процес кооперування, дійшов висновку про можливість і доцільність його прискорення і завершення протягом найближчих 3 років. Так чи інакше, сумніви Дамби в методах досягнення суцільного кооперування аратських господарств не відповідали загальним зусиллям Східного блоку щодо посилення соціалістичного контролю над сільським господарством i, звичайно, “не відповідали амбіціям Цеденбала щодо негайного катапультування Монголії у XX століття” за допомогою радянського досвіду [CIWS, September 29, 1960]. 
Ю. Цеденбал лобіював політику кооперування аратських господарств ще за часів Чойбалсана, який не поділяв ентузіазму свого протеже в цьому питанні. Цеденбал зміг розпочати новий виток колективізації лише після смерті маршала, в 1953 році, коли негдели (монг. нэгдэл; колективи) контролювали понад 3 відсотки поголів'я худоби в країні [Christian 2018, 481-482]. Основним виправданням нового раунду колективізації було підвищення технічного рівня тваринництва, яке, як і раніше, залишалося основним видом економічної діяльності країни. У меморандумі, який містив стислі відомості щодо політичного, економічного та культурного життя в МНР і супроводжував заявку країни про прийняття в члени ООН від 1 вересня 1957 р., також підкреслювалося, що уряд надає всебічну допомогу сільськогосподарському кооперуванню, яке здійснюється на суто добровільній основі. Усвідомлюючи трагедію таких спроб, що відбувалися на початку 1930-х років, монгольський уряд запроваджував колективізацію більш обережно і менш жорстко, більше покладаючись на економічний тиск: держава стягувала 3 колективів аратів нижчі обов'язкові квоти і податки, надаючи їм великі ділянки пасовищ, а також ветеринарні та технічні послуги [Christian 2018, 481-482]. Водночас примус завжди існував. Так, радянський посол в Улан-Баторі В. М. Молотов посилався на закритий лист ЦК МНРП від 2 січня 1959 р., де містилася вимога, “щоб ті члени партії - скотарі, які ще не вступили в об'єднання, зараз же вступили в них... Ті члени партії, які стоять осторонь від руху за кооперування, мають зрозуміти, що в партії не місце тим, що не беруть участі своєю патріотичною працею у великій справі соціалістичного перетворення найвідсталішої галузі нашої економіки" (цит. за: [История Монголии... 2007, 270]). Наприкінці 1950-х рр. в МНР переважно був завершений процес масового кооперування одноосібних аратських господарств. Втративши більшу частину свого багатства і капіталу, взявши на себе відповідальність за збереження і примноження громадського стада і не діставши адекватної оцінки та винагороди за важку працю, багато аратів поступово втратили економічні і моральні стимули до інтенсивної праці в колективному господарстві [История Монголии... 2007, 298].

Ш. Надіров зафіксував доволі показову розмову з Цеденбалом, яка може бути гарною ілюстрацією робочих стосунків між двома монгольськими правителями. «“Якось вранці, - розповідав Ю. Цеденбал автору (Ш. Надірову. - I. O.), - дзвонить мені по телефону Дамба і каже: «Слухай, Цеденбал, ти зайди до мене...»”. Голосно розсміявшись, він продовжував свою розповідь: “«Ти сам зайди до мене!» - сказав я Дамбі. Той помовчав трохи, щось прохрипів у трубку і каже: «Гаразд, зайду». I зайшов!"’. Ю. Цеденбал засміявся ще голосніше, повертаючись, мабуть, подумки до цього досить комічного епізоду. Потім, після невеликої паузи, вже серйозним тоном додав: “Звичайно, справа зводилася не до дрібного самолюбства: хто до кого має ходити... Чойбалсан, бувши прем'єр-міністром і відповідно першою особою в державі, частенько заходив до мене. Але, природно, не за викликом моїм - я не міг навіть думати про це. Він заходив просто сам, щоб щось повідомити мені, домовитися про щось. I це сприймалося як звичайне явище, але у випадку з Дамбою була зовсім інша ситуація: вирішувалося питання про владу, у чиїх руках вона опиниться. Дамба був сам по собі непоганою людиною, але йому не вистачало знань, по суті він не мав освіти. I небезпечним було те, що за його спиною стояли дуже обмежені 3 політичного погляду люди. Якби влада опинилася в їхніх руках, невідомо, що могло б статися з країною"» [Надиров 1995, 174].

Наведений уривок свідчить багато про що: про всю двозначність колективного керівництва, яка в монгольських умовах ще й накладалась на політичну практику попередніх десятиліть, коли партія зі своїми претензіями на вищу владу в країні спочатку вимушено відступала в тінь, а потім повільно відвойовувала свої позиції, спираючись на радянську підтримку. Потім партійний провід разом з усіма повноваженнями переважно зосереджувався в руках монгольського прем'єра. Ми бачимо 
серйозність тодішньої боротьби за владу між прем'єром та партійним очільником і що Цеденбал у цьому контексті згадував свої власні відносини з Чойбалсаном, коли ще сам був генеральним секретарем ЦК МНРП. Бачимо знов-таки його ставлення до Дамби і головний закид - щодо відсутності в останнього освіти, сумніви щодо його оточення.

Як можна зрозуміти, врешті-решт, Цеденбалу вдалося заручитися згодою Москви на ротацію в монгольських владних колах. Після поїздки Цеденбала в Москву (де наприкінці жовтня він встиг поспілкуватися з М. Хрущовим) у листопаді 1958 р. ЦК МНРП зібрався на пленарне засідання, після чого Цеденбал знову став першим секретарем, а Дамба знову - другим секретарем “задля кращої централізації партійного керівництва" [CIWS, November 26, 1958]. На початок 1959 року Цеденбал ще зміцнив свої позиції і черговий раз відвідав Москву, завітавши вже як 1-й секретар на XXI з’їзд КПРС (27.01 - 5.02.1959). Протиборство на монгольському Олімпі закінчилося тим, що вищезгаданий ІІІ пленум ЦК МНРП 31 березня 1959 р. відсторонив Д. Дамбу від керівної партійної роботи “за безпринципність, нещирість перед партією, за ідейно-політичну відсталість, консерватизм та інерцію” разом із п’ятьма іншими членами Політбюро (цит. за: [Надиров 1995, 74]). На думку західних спостерігачів, звинувачення проти Дамби були образливими і розкривали всю глибину ворожості Цеденбала (Цеденбал, зокрема, розкритикував Дамбу за його початкову освіту і незнання російської мови), а також свідчили про те, що Москва поділяє ці почуття [CIWS, September 29, 1960]. 4 квітня 1960 р. в монгольській щоденній газеті Унэн (орган ЦК МНРП і Ради Міністрів МНР) з'явилася розлога стаття, у якій обговорювались недоліки колишнього партійного очільника і “з якої ставало зрозуміло, що постать Дамби тепер є уособленням інакодумства, якого слід уникати будь-якою ціною для успішного політичного розвитку" [Communist Revisionism and Dissidence...]. В листопаді 1959 р. Дамба був відправлений на заслання - працювати директором тваринницької станції у віддаленому Хубсугульському аймаку. У 1962 році він став заступником директора Інституту сільського господарства і займав цю посаду до 1977 року. Лише у 1990 році ЦК МНРП визнав звинувачення проти Дамби необгрунтованими, а в 2008 році районний суд Сухе-Батора оголосив його жертвою репресій [Sanders 2010, 186-187]. Цеденбал же, як відомо, правив МНР до 1984 р., коли був усунутий від влади за ініціативи радянської сторони.

В одному з Current Intelligence Weekly Summary експерти, аналізуючи крах колективного керівництва в МНР, влучно зазначали, що здається, ніби Дамба спробував обережно послабити радянську присутність під час свого п'ятирічного контролю над партією. Його готовність протистояти радянській фракції і бажання врахувати монгольські особливості при реформуванні економіки вказують на це, надаючи боротьбі Дамби за особисту владу виразно націоналістичний відтінок. Саме під час правління Дамби китайський вплив у МНР дещо відродився, що перший секретар ЦК МНРП, ймовірно, вітав, але лише тією мірою, якою це могло трохи компенсувати радянський контроль [CIWS, September 29, 1960]. Водночас Дамба, бувши першим секретарем МНРП, на думку деяких авторів, не виявляв старанності у виступах проти югославського “ревізіонізму” і “націоналістичних тенденцій”, що коштувало йому підтримки не лише в Москві, а й у Пекіні. I, нарешті, після того, як претензії китайських комуністів на ідеологічне лідерство всередині комуністичного блоку були явно розвіяні на XXI з'їзді КПРС, Дамба втратив підтримку з цього боку і став уразливим у боротьбі з підтримуваним Москвою Цеденбалом [Geisler 1959, 187].

Після усунення Дамби боротьба Цеденбала з іншими представниками монгольської правлячої верхівки тривала впродовж наступних п'яти років, зокрема 3 наступником Дамби на посаді 2-го секретаря ЦК МНРП - Л. Цендом (монг. Л. Цэнд; 1959-1963). Цеденбал вийшов переможцем з цих політичних баталій, усунувши своїх опонентів від влади та відправивши їх на заслання до віддалених аймаків 
МНР. Посаду очільника ЦК МНРП він вже не випускав зі своїх рук, зберігаючи ії до серпня 1984 р. Тоді він був позбавлений всіх посад у МНР і відправлений до СРСР, де провів останні роки свого життя.

\section{Висновки}

Авторка доходить висновку, що окрім боротьби за владу, яка протягом і попередніх десятиліть точилася між монгольськими прем'єрами та першими секретарями ЦК МНРП, у цьому разі додалися принципові відмінності в поглядах монгольських правителів. Це були різні погляди на темпи та умови кооперації аратських господарств, на демаркацію кордону між МНР та СРСР - надзвичайно важливі для монгольського суспільства речі.

Найгострішим напрямом у взаємній боротьбі двох монгольських політичних лідерів стали переосмислення та розслідування політичних репресій, що відбулися в 1930-1940-х рр. в МНР. 3 одного боку, ця трагедія монгольського народу залишалася актуальною впродовж десятиліть, до неї апелювали різні когорти та покоління монгольських політиків у другій половині XX ст. 3 другого - тоді розслідування злочинів попереднього режиму правило потужною зброєю в боротьбі за одноосібну владу в соціалістичній країні, за зразком радянського партійного очільника М. С. Хрущова. Друга половина 1950-х рр. стала важким випробуванням для Ю. Цеденбала, який боровся не лише за владу, що почала вислизати з рук, а й із власним минулим.

Вивчаючи цей поєдинок першого секретаря партії та прем'єра і звертаючи увагу на те, що їх розділяло, бачиш багато в чому зіткнення представника монгольського світу 3 представником радянського, людей з різним бекграундом, системою цінностей, баченням. Схожі відмінності у важливих, принципових питаннях були свого часу і між Цеденбалом та Чойбалсаном, здається, з цієї ж причини. Водночас, деякі науковці вважають, що хоча в поглядах Цеденбала не було помітно прихильності до етнічного націоналізму, у певних аспектах їх можна було б охарактеризувати як громадянський, державоцентричний націоналізм [Szalontai 2005, 95]. Також слід зазначити, що, наприклад, на вирішення питання демаркації кордону у 1950-ті рр. навряд чи вплинула особиста позиція Цеденебала. Швидше за все, він був змушений поступитися тиску радянської сторони, усвідомлюючи важливість радянської підтримки для МНР.

На монгольське політичне життя впливали нестійка політична кон'юнктура в радянській керівній верхівці та Східному блоці та накладання одне на одного повноважень глави держави і глави ЦК партії в країнах соціалістичного табору. Вирішальним фактором також був ступінь радянської підтримки того чи іншого політика, що базувався насамперед на мірі лояльності останнього до СРСР.

Усунення Д. Дамби та його прибічників з політичної арени не позбавило Ю. Цеденбала серйозної опозиції та подальших непоодиноких викликів його владі, що, зокрема, свідчить: вищі монгольські посадовці мали серйозні підстави для невдоволення політичною лінією прем’єра.

${ }^{1}$ Ш. Надіров як радник, пізніше радник-посланник Посольства СРСР в МНР співпрацював з Ю. Цеденбалом у 1962-1969 рр., а надалі супроводжував його під час візитів монгольського політика до СРСР.

${ }^{2}$ На жаль, авторці вдалося ознайомитись лише з одним розділом цієї книжки, присвяченим якраз конфлікту між Цеденбалом і Дамбою (див.: Дашийн Дамба // Baabar.mn. 2017.11.15. URL: http://43.231.113.32/article/dashiin-damba (дата звернення: 25.10.2020)).

${ }^{3}$ Автор грунтовної праці “Цеденбал и его время” (у 2 томах) - Л. І. Шинкарьов, радянський та російський журналіст і письменник, який працював кореспондентом “Известий” в 
МНР у 1977-1981 pp. В основу праці покладені, зокрема, зібрані ним інтерв’ю з багатьма дійовими особами “епохи Цеденбала". Для нас наразі особливий інтерес становлять інтерв’ю дружини Цеденбала А. І. Філатової та Б. Ширендева (монг. Ширэндэв), голови монгольської комісії для перегляду справ репресованих у 1930-1940-ві рр.

${ }^{4}$ У записці “Обстановка в МНР у зв'язку зі смертю маршала Чойбалсана”, що збереглася серед паперів В. Молотова, серед наступників Х. Чойбалсана на посаді прем'єра називали Г. Бумценда (монг. Г. Бумцэнд), голову президії Великого Хуралу, Ю. Цеденбала і Ч. Суренжава (монг. Сурэнжав), першого заступника прем'єр-міністра [РГАСПИ, ф. 82, оп. 2, д. 1280, л. 27-28].

${ }^{5}$ Йдеться про халха-монголів - найчисленніший народ Монголії.

6 Дербети (монг. дөрвөд) - монгольська етнічна група, що входить до складу ойратів, у Західній Монголії.

7 У 1957 р. В. М. Молотова призначили послом СРСР в МНР, на цій посаді він пропрацював до липня 1960 р. Отже, вся драматична колізія між Цеденбалом і Дамбою розгорталася на його очах.

${ }^{8}$ Худон (монг.) - сільська місцевість, провінція.

${ }^{9}$ Тоді заарештували 70 китайців, які нібито готували замах на Чойбалсана, майже половину з них відразу ж розстріляли [Шинкарев 2006, 175].

${ }^{10}$ Дашийн Дамба // Baabar.mn. 2017.11.15. URL: http://43.231.113.32/article/dashiin-damba (дата звернення: 25.10.2020).

${ }^{11}$ Дашийн Дамба // Baabar.mn. 2017.11.15. URL: http://43.231.113.32/article/dashiin-damba (дата звернення: 25.10.2020).

1225 лютого 1956 р., заслухавши доповідь М. С. Хрущова "Про культ особи та його наслідки”, ХХ з'їзд КПРС схвалює положення доповіді Центрального комітету і доручає ЦК КПРС послідовно здійснювати заходи, що забезпечують повне подолання чужого марксизму-ленінізму культу особи, ліквідацію його наслідків у всіх галузях партійної, державної та ідеологічної роботи, "суворе проведення норм партійного життя і принципів колективності керівництва, вироблених великим Леніним” [Реабилитация: как это было... 2000, 380]. Керівникам зарубіжних компартій, які приїхали як гості на з'їзд до Москви, але не були присутні на його закритому засіданні (серед них був і Д. Дамба), текст доповіді та постанова з'їзду через відділ ЦК зі зв'язків з іноземними компартіями були передані вже 27 лютого 1956 р. Матеріали підлягали поверненню до від'іззду зазначених осіб з Москви.

13 За словами Б. Ширендева, який очолював у 1956-1957 рр. спеціальну комісію з перегляду справ репресованих, усі документи про арешти і страти в період з 1940-го по 1952 р. підписувала “трійка", у якій вирішальне слово було за Чойбалсаном та Цеденбалом [Шинкарев 2006, 175].

14 За спогадами його дружини, тоді ночами Цеденбал прокидався і кричав: “Я нікого не розстрілював!" [Шинкарев 2006, 175].

${ }^{15} 1958$ оны Монгол, Зөвлөлтийн хилийн хэлэлцээр // Vip Expert. 2009.09.07. URL: https:// vip76.mn/content/6836 (дата звернення: 25.10.2020).

${ }^{16}$ Треба зауважити, що переговори йшли навколо земель на крайньому північному заході Монголії, де була, зокрема, мала батьківщина Ю. Цеденбала.

${ }^{17}$ Міністр закордонних справ МНР С. Аварзед (монг. С. Аварзэд; 1922-1989) виступив проти вимог В. Молотова щодо територіальних поступок і згодом втратив роботу за "антирадянську позицію”. Звинувачення в антирадянщині були зняті лише в 1990 році, незабаром після того, як Аварзед помер від удару вантажівки [New Documents on Mongolia... 2007/2008, 347].

18 Йдеться про зустріч лідерів країн, що входили до Ради економічної взаємодопомоги (РЕВ). Такі конференції проводились у Москві в травні 1958 р., лютому 1960 р., червні 1962 p. та липні 1963 p. тощо, і на той час саме на них ухвалювались найважливіші рішення щодо цієї організації. МНР стала членом РЕВ у 1962 p.

${ }^{19}$ Більше про монголо-китайські відносини цього періоду див.: [New Documents on Mongolia... 2007/2008; CIWS, September 29, 1960 та ін.].

${ }^{20}$ Ця дискусія мала своє продовження, зокрема в 1960-х рр. багато монгольських інтелектуалів вважали, що швидка модернізація руйнує національні традиції, тоді як Цеденбал та його прибічники вважали культурний спадок Монголії тим фактором, що суттєво стримує поступ країни [Szalontai 2005, 94]. 


\section{ЛІТЕРАТУРА}

Даниленко В. Політичні зміни в СРСР і Україні в період хрущовської “відлиги” // Україна ХХ ст.: культура, ідеологія, політика. Вип. 14. Київ, 2008.

История Монголии. ХХ век. Москва, 2007.

Капииа М. С. На разных параллелях. Записки дипломата. Москва, 1996.

МАХН-ын 13 их хурлын материал (1958 оны 3-р сарын 17-22). Улаанбаатар, 1958.

Надиров Ш. Г. Цеденбал. 1984 год. Москва, 1995.

Отрощенко I. B. У пошуках порозуміння: монгольсько-тувинські взаємини у першій половині 1940-х рр. // Сходознавство, 2019, № 84.

Реабилитация: как это было. Документы Президиума ЦК КПСС и другие материалы. В 3-х т. Т. 1. Март 1953 - февраль 1956. Москва, 2000.

Российский государственный архив социально-политической истории (РГАСПИ). Ф. 82, оп. 2, д. 1280-1281.

Сто сорок бесед с Молотовым: Из дневника Ф. Чуева. Москва, 1991.

Шинкарев Л. И. Цеденбал и его время: в 2 т. Т. 1: Любовь. Власть. Трагедия. Москва, 2006. Atwood Christopher Pratt. Encyclopedia of Mongolia and the Mongol empire. New York, 2004. Christian David. A History of Russia, Central Asia and Mongolia. Vol. II: Inner Eurasia from the Mongol Empire to Today, 1260-2000. Wiley-Blackwell, 2018.

Communist Revisionism and Dissidence, July 8, 1960 // Central Intelligence Agency (CIA). URL: https://www.cia.gov/readingroom/docs/CIA-RDP78-00915R001200120003-2.pdf (дата звернення: 25.10.2020).

Current Intelligence Weekly Summary (CIWS), April 3, 1958 // Central Intelligence Agency (CIA). URL: https://www.cia.gov/readingroom/docs/CIA-RDP79-00927A001700040001-0.pdf (дата звернення: 25.10.2020).

CIWS, November 26, 1958 // Central Intelligence Agency (CIA). URL: https://www.cia.gov/ readingroom/docs/CIA-RDP79-00927A002000050001-5.pdf (дата звернення: 25.10.2020).

CIWS, April 2, 1959 // Central Intelligence Agency (CIA). URL: https://www.cia.gov/readingroom/docs/CIA-RDP79-00927A002200040001-4.pdf (дата звернення: 25.10.2020).

CIWS, April 16, 1959 // Central Intelligence Agency (CIA). URL: https://www.cia.gov/readingroom/docs/CIA-RDP79-00927A002200060001-2.pdf (дата звернення: 25.10.2020).

CIWS, September 29, 1960 // Central Intelligence Agency (CIA). URL: https://www.cia. gov/readingroom/docs/CIA-RDP79-00927A002900050001-7.pdf (дата звернення: 25.10.2020).

Geisler Richard A. Recent Developments in Outer Mongolia // Far Eastern Survey. Vol. 28, No. 12.1959.

Myadar Orhon. In the Soviet Shadow. Soviet Colonial Politics in Mongolia // Inner Asia. Vol. 19, Issue 1. 2017.

New Documents on Mongolia and the Cold War // Cold War International History Project Bulletin. Issue 16. 2007/2008.

Radchenko Sergey. Power Struggle in Socialist Mongolia: Review of Two Political Memoirs // Inner Asia. Vol. 7, Issue 2. 2005.

Radchenko Sergey. Mongolian Politics in the Shadow of the Cold War: The 1964 Coup Attempt and the Sino-Soviet Split // Journal of Cold War Studies. Vol. 8, No. 1. 2006.

Rupen Robert A. Outer Mongolia, 1957-1960 // Pacific Affairs. Vol. 33. No. 2. 1960.

Sanders Alan J. K. Historical Dictionary of Mongolia. Scarecrow Press, 2010.

Socialist Devotees and Dissenters: Three Twentieth-Century Mongolian Leaders / Interviews Conducted by Yuki Konagaya and I. Lkhagvasuren, Translated by Mary Rossabi, Edited and Compiled by Morris Rossabi. Osaka, 2011.

Szalontai B. Tsedenbal's Mongolia and Communist Aid Donors: A Reappraisal // The Mongolian Journal of International Affairs, 2005, No. 12.

The Concise Oxford Dictionary of Politics and International Relations / Garrett W. Brown, Iain McLean, Alistair McMillan. 4 ed. Oxford University Press, 2018.

\section{REFERENCES}

Danylenko Viktor (2008), "Politychni zminy v SRSR i Ukrayini v period khrushchovs'koyi 'vidlyhy'”, in Ukrayina XX st.: kul 'tura, ideolohiya, polityka, Issue 14, pp. 3-17.

Istoriya Mongolii. XX vek (2007), IV RAN, Moscow. (In Russian). 
Kapitsa M. S. (1996), Na raznykh parallelyakh. Zapiski diplomata, Kniga i biznes, Moscow. (In Russian).

Mongol Ardyn Khuvisgalt Namyn XIII ikh khurlyn material (1958 ony 3-r saryn 17-22) (1958), UKhG, Ulaanbaatar. (In Mongol).

Nadirov Sh. G. (1995), Tsedenbal. 1984 god, Vostochnaya literatura, Moscow. (In Russian).

Otroshchenko I. V. (2019), "U poshukakh porozuminnya: monhol's'ko-tuvyns'ki vzayemyny u pershiy polovyni 1940-kh rr.", Skhodoznavstvo, No. 84, pp. 85-104. (In Ukrainian).

Reabilitatsiya: kak eto bylo. Dokumenty Prezidiuma TsK KPSS i drugiye materialy (2000), In 3 vols, Vol. 1: Mart 1953 - fevral' 1956, Mezhdunarodnyy Fond "Demokratiya", Moscow. (In Russian).

Rossiyskiy gosudarstvennyy arkhiv sotsial'no-politicheskoy istorii (RGASPI) [The Russian State Archive of Socio-Political History], Fund 82, Inventory 2, Files 1280-1281.

Sto sorok besed s Molotovym: Iz dnevnika F. Chuyeva (1991), TERRA, Moscow. (In Russian).

Shinkarev L. I. (2006), Tsedenbal i ego vremya: in 2 vols, Vol. 1: Lyubov'. Vlast'. Tragediya, Sobraniye, Moscow. (In Russian).

Atwood C. P. (2004), Encyclopedia of Mongolia and the Mongol empire, Facts on File, New York.

Christian David (2018), A History of Russia, Central Asia and Mongolia, Vol. II: Inner Eurasia from the Mongol Empire to Today, 1260-2000, Wiley-Blackwell.

"Communist Revisionism and Dissidence, July 8, 1960", Central Intelligence Agency (CIA), available at: https://www.cia.gov/readingroom/docs/CIA-RDP78-00915R001200120003-2.pdf (accessed October 25, 2020).

"Current Intelligence Weekly Summary (CIWS), April 3, 1958", Central Intelligence Agency (CIA), available at: https://www.cia.gov/readingroom/docs/CIA-RDP79-00927A001700040001-0. pdf (accessed October 25, 2020).

"Current Intelligence Weekly Summary (CIWS), November 26, 1958", Central Intelligence Agency (CIA), available at: https://www.cia.gov/readingroom/docs/CIA-RDP79-00927A0020000 50001-5.pdf (accessed October 25, 2020).

"Current Intelligence Weekly Summary (CIWS), April 2, 1959", Central Intelligence Agency (CIA), available at: https://www.cia.gov/readingroom/docs/CIA-RDP79-00927A002200040001-4. pdf (accessed October 25, 2020).

"Current Intelligence Weekly Summary (CIWS), April 16, 1959", Central Intelligence Agency (CIA), available at: https://www.cia.gov/readingroom/docs/CIA-RDP79-00927A002200060001-2. pdf (accessed October 25, 2020).

"Current Intelligence Weekly Summary (CIWS), September 29, 1960", Central Intelligence Agency (CIA), available at: https://www.cia.gov/readingroom/docs/CIA-RDP79-00927A0029000 50001-7.pdf (accessed October 25, 2020).

Geisler Richard A. (1959), "Recent Developments in Outer Mongolia", Far Eastern Survey, Vol. 28, No. 12, pp. 182-188.

Myadar Orhon (2017), "In the Soviet Shadow. Soviet Colonial Politics in Mongolia", Inner Asia, Vol. 19, Issue 1, pp. 5-28.

"New Documents on Mongolia and the Cold War" (2007/2008), Cold War International History Project Bulletin, Issue 16, pp. 341-366.

Radchenko Sergey (2005), "Power Struggle in Socialist Mongolia: Review of Two Political Memoirs", Inner Asia, Vol. 7, Issue 2, pp. 275-84.

Radchenko Sergey (2006), "Mongolian Politics in the Shadow of the Cold War: The 1964 Coup Attempt and the Sino-Soviet Split", Journal of Cold War Studies, Vol. 8, No. 1, pp. 95-119.

Rupen Robert A. (1960), "Outer Mongolia, 1957-1960", Pacific Affairs, Vol. 33, No. 2, pp. 126-143.

Sanders Alan J. K. (2010), Historical Dictionary of Mongolia, Scarecrow Press.

Socialist Devotees and Dissenters: Three Twentieth-Century Mongolian Leaders (2011), Interviews Conducted by Yuki Konagaya and I. Lkhagvasuren, Translated by Mary Rossabi, Edited and Compiled by Morris Rossabi, National Museum of Ethnology, Osaka.

Szalontai B. (2005), "Tsedenbal's Mongolia and the Communist Aid Donors: A Reappraisal", The Mongolian Journal of International Affairs, No. 12, pp. 91-95.

The Concise Oxford Dictionary of Politics and International Relations (2018), Garrett W. Brown, Iain McLean, Alistair McMillan (eds), 4 ed., Oxford University Press. 


\section{I. В. Отрощенко \\ Колективне керівництво та боротьба за владу в МНР 1950-х рр.: Ю. Цеденбал і Д. Дамба}

У статті, побудованій, зокрема, на неопублікованих джерелах, аналізується суперництво між прем'єр-міністром та очільником Монгольської народно-революційної партії (МНРП) (Ю. Цеденбал і Д. Дамба) в політичних реаліях Монгольської Народної Республіки (МНР) 1950-х рр. (період колективного керівництва). На думку авторки, окрім боротьби за владу, що протягом і попередніх десятиліть точилася між монгольськими прем'єрами та першими секретарями ЦК МНРП, у цьому разі додалися принципові відмінності в поглядах монгольських правителів. Це були різні погляди на темпи та умови кооперації аратських господарств, на демаркацію кордону між МНР та СРСР - надзвичайно важливі для монгольського суспільства речі.

Найгострішим напрямом у взаємній боротьбі двох монгольських політичних лідерів стали переосмислення та розслідування політичних репресій, що відбулися в 1930-1940-х рр. в МНР. 3 одного боку, ця трагедія монгольського народу залишалася актуальною впродовж десятиліть, до неї апелювали різні когорти та покоління монгольських політиків у другій половині XX ст. 3 другого - тоді розслідування злочинів попереднього режиму правило потужною зброєю в боротьбі за одноосібну владу в соціалістичній країні, за зразком радянського партійного очільника М. С. Хрущова. Отже, друга половина 1950-х рр. стала важким випробуванням для Цеденбала, який боровся не лише за владу, що почала вислизати з рук, а й із власним минулим. На монгольське політичне життя впливали нестійка політична кон'юнктура в радянській керівній верхівці та Східному блоці та накладання одне на одного повноважень глави держави і глави ЦК партії в країнах соціалістичного табору. Вирішальним фактором також був ступінь радянської підтримки того чи іншого політика, що базувався насамперед на мірі лояльності останнього до СРСР. Усунення Д. Дамби та його прибічників з політичної арени не позбавило Ю. Цеденбала серйозної опозиції та подальших непоодиноких викликів його владі, що, зокрема, свідчить: вищі монгольські посадовці мали серйозні підстави для невдоволення політичною лінією прем'єра.

Ключові слова: Монгольська Народна Республіка (МНР), СРСР, Монгольська народнореволюційна партія (МНРП), прем’єр-міністр, перший секретар ЦК МНРП, колективне керівництво, Ю. Цеденбал, Д. Дамба, політичні репресії

Стаття надійшла до редакиії 18.11.2020 